\title{
Penggunaan Message Appeals dalam Strategi Pesan Kampanye Anti Kekerasan Berbasis Gender Online
}

\author{
Eny Ratnasari ${ }^{1}$ Suwandi Sumartias $^{2}$, Rosnandar Romli ${ }^{3}$ \\ 1,2,3 Fakultas Ilmu Komunikasi, Universitas Padjadjaran \\ Jl. Raya Bandung-Sumedang KM 21, Jatinangor, Kabupaten Sumedang, Jawa Barat, 45363, Indonesia \\ Email: eny12001@mail.unpad.ac.id ${ }^{1 *}$; suwandi.sumartias@unpad.ac.id²; rosnandar.romli@unpad.ac.id³ \\ *Corresponding author
}

\begin{abstract}
The increasing number of Online Gender-Based Violence(OGBV) cases in the last six years has made Digital AtRisks Sub-Division of SAFEnet (Southeast Asia Freedom of Expression Network) made "Awas KBGO!" (Beware of OGBV!) Campaign to give a warning to the public. The use of message appeals as message strategy still doesn't work to increase public awareness. This research to analyze on knowing the strengths and challenges of using message appeals as message strategy on "Awas KBGO!" Campaign. The research method that used is a case study at SAFEnet (non-profit organization) with data collection techniques, such as interviews, observation, and literature study. The results showed that the "Awas KBGO!" using the message appeals strategy which is divided into two, reasoning appeals and emotional appeals. Emotional appeals that are used generate two feelings, namely positive feelings and negative feelings. The use of campaign messages that create negative feelings in the form of fear appeals is more dominant than positive messages. The strength of the campaign message was in the use of data and facts, meanwhile fear appeals are a challenge because it creates uncomfortable feelings for target audience. The substance of this research contributes in the form of new policy recommendations for SAFEnet to produce humanized campaign messages with positive narration and storytelling techniques. Keywords: Campaign Message Strategy; Message Appeals; Online Gender-Based Violence (OGBV); Social Campaign
\end{abstract}

\begin{abstract}
Abstrak
Meningkatnya kasus Kekerasan Berbasis Gender Online (KBGO) dalam enam tahun terakhir membuat Sub Divisi Digital At-Risks SAFEnet (Southeast Asia Freedom of Expression Network) melakukan Kampanye "Awas KBGO!" untuk memberikan warning kepada publik. Strategi pesan dengan menggunakan daya tarik pesan masih belum berhasil untuk meningkatkan awareness publik. Penelitian ini berfokus untuk menganalisis kekuatan dan tantangan penggunaan message appeals dalam strategi pesan Kampanye "Awas KBGO!". Metode penelitian yang digunakan adalah studi kasus pada organisasi nirlaba SAFEnet dengan teknik pengumpulan data yakni wawancara, observasi, dan studi pustaka. Hasil penelitian menunjukkan bahwa Kampanye "Awas KBGO!" menggunakan strategi pesan message appeals (daya tarik pesan) yang terbagi menjadi dua yaitu reasoning appeals (daya tarik alasan) dan emotional appeals (daya tarik emosional). Emotional appeals yang digunakan menimbulkan dua perasaan yaitu perasaan positif dan perasaan negatif. Penggunaan pesan kampanye yang menimbulkan perasaan negatif berupa fear appeals lebih dominan dibandingkan dengan pesan positif. Kekuatan pesan kampanye terletak pada penggunaan data dan fakta, sedangkan fear appeals justru menjadi tantangan karena menimbulkan perasaan tidak nyaman bagi target audiens. Substansi penelitian ini memberikan kontribusi berupa rekomendasi kebijakan baru kepada SAFEnet untuk memperbanyak pesan kampanye yang memanusiakan (humanize) dengan narasi positif dan teknik storytelling. Kata kunci: Strategi Pesan Kampanye; Message Appeals; Kekerasan Berbasis Gender Online (KBGO); Kampanye Sosial
\end{abstract}

\section{Pendahuluan}

Komnas Perempuan mencatat adanya kekerasan terhadap gender jenis baru yaitu kekerasan gender berbasis siber atau online. Kasus kekerasan ini terus mengalami peningkatan selama enam tahun terakhir (Komnas Perempuan, 2020). Selama masa pandemi
COVID-19, Lembaga Bantuan Hukum APIK Jakarta menyatakan bahwa angka kasus KBGO melonjak tajam hingga menempati posisi kedua setelah kasus Kekerasan Dalam Rumah Tangga (KDRT). Setiap hari ada satu kasus kekerasan berbasis gender online yang dilaporkan ke LBH APIK Jakarta (LBH APIK Jakarta, 2020). 
Kekerasan Berbasis Gender Online atau KBGO adalah segala bentuk tindakan yang membuat seseorang tidak aman atau merasa tidak aman, menyerang gender atau seksualitas seseorang, serta difasilitasi oleh internet dan teknologi. KBGO biasanya disebabkan oleh pelanggaran privasi dan/atau melakukan tindakan yang tidak berdasarkan persetujuan (konsensual) pada satu atau banyak individu sekaligus (SAFEnet, 2019).

International Center for Research on Women mengistilahkan Kekerasan Berbasis Gender Online sebagai TechnologyFacilitated Gender Based Violence (TFGBV). Kekerasan ini meliputi penguntitan (stalking), penindasan (bullying), pelecehan seksual (sexual harassment), pencemaran nama baik (defamation), ujaran kebencian (hate speech), eksploitasi (exploitation), dan gender trolling (Mueller, Brien-milne, \& Wandera, 2018).

Merujuk Catatan Tahunan Komnas Perempuan Tahun 2020, ada peningkatan sebesar 300\% pada Kekerasan Berbasis Gender Online (KBGO) dibandingkan tahun sebelumnya (2019) (Komnas Perempuan, 2020). Komnas Perempuan menyatakan bahwa kekerasan jenis ini memiliki pola kekerasan yang semakin rumit karena terjadi dalam ranah digital. Mulai dari pembunuhan karakter hingga pelecehan seksual melalui serangan di dunia maya. Dampak KBGO sama seperti kekerasan seksual yang terjadi di dunia nyata, dampaknya dirasakan langsung dan berjangka panjang pada korban. Pelaku sulit dideteksi serta respon dan perlindungan hukum di Indonesia juga belum memadai karena disederhanakan dalam ranah UU ITE (Komnas Perempuan, 2017).

Kekerasan Berbasis Gender Online (KBGO) adalah kekerasan jenis baru yang terjadi karena perkembangan teknologi. Masyarakat Indonesia masih salah kaprah tentang pengertian kekerasan berbasis gender terlebih kekerasan berbasis gender online. Banyak diantara masyarakat yang belum memahami bentukbentuk kekerasan yang dapat menyerang identitas gender di ranah digital khususnya perempuan dan minoritas gender lainnya.
Adanya peningkatan kasus KBGO dan kurangnya awareness masyarakat tentang isu ini kemudian membuat SAFEnet (Southeast Asia Freedom of Expression Network) sebagai organisasi nirlaba yang memperjuangkan hakhak digital melakukan Kampanye Anti Kekerasan Berbasis Gender Online (KBGO). Kampanye sosialini diberinama “AwasKBGO!". Sejaktahun 2019, kampanye dilakukan dengan memberikan edukasi dan pemahaman pada publik untuk mengenali, mencegah, dan menyikapi kekerasan berbasis gender online. Sejak kampanye ini diluncurkan, SAFEnet melakukan serangkaian kegiatan baik secara online maupun offline. Selama masa pandemi, SAFEnet lebih banyak melakukan secara online dengan memanfaatkan infrastruktur digital untuk menyebarkan pesan kampanye melalui konten-konten di media sosial.

Usaha dari Sub Divisi Digital At-Risks SAFEnet untuk membuat sebuah kampanye yang bertemakan anti kekerasan gender berbasis online adalah sebuah keberanian. Sebagai satu-satunya organisasi nirlaba di Indonesia yang memperjuangkan hak-hak digital dan memiliki kredibilitas untuk menyuarakan tentang keamanan digital, bukan kewajiban SAFEnet untuk membuat kampanye yang berhubungan dengan gender seperti "Awas KBGO!" ini. Kekerasan berbasis gender online difasilitasi oleh teknologi dan tempat kejadian perkara berkaitan dengan teknologi, pada akhirnya SAFEnet membuat kampanye ini. Meski SAFEnet menyadari bahwa kampanye ini tidak dapat dipisahkan dari isu gender dan budaya patriarki yang ada di Indonesia.

Tantangan budaya patriarki di Indonesia membuat kampanye ini menjadi kurang diminati oleh masyarakat. Padahal pesan kampanye “Awas KBGO!" penting sebagai langkah preventif dan kuratif. Preventif untuk melindungi diri sendiri dan kuratif karena sistem hukum di Indonesia belum mendukung penanganan kasus KBGO. Tantangan lainnya adalah literasi keamanan digital masyarakat Indonesia yang masih rendah sehingga membuat masyarakat belum memiliki self sensor awareness (Novianti \& Fatonah, 2018; Wisanggeni, 2020). 
SAFEnet pun berusaha untuk mengemas pesan kampanye dengan mengkombinasikan unsur literasi keamanan digital, gender, dan kekerasan berbasis gender online. Peneliti menemukan bahwa SAFEnet lebih dominan menggunakan daya tarik pesan (message appeals) yang menimbulkan emosi negatif yakni fear appeals (pendekatan rasa takut). Fear appeals pada dasarnya merupakan pesan persuasif yang didesain untuk menakuti khalayak dengan menggambarkan hal-hal buruk yang akan terjadi pada mereka bila tidak menuruti perintah yang dilakukan. Pesan ini biasanya menggunakan bahasa yang hidup, personal, dan mengandung muatan informasi yang menarik dengan berbagai detailnya (Witte, 1993, 1996).

Saat kampanye sosial, pesan adalah yang utama. Hal ini dikarenakan inti dari kampanye adalah pesan. Kampanye mengandalkan kekuatannya untuk memengaruhi khalayak melalui pesan-pesan yang dirancang secara kreatif, sistematis, dan efektif (Venus, 2018). Message appeals adalah komponen kunci dari kampanye komunikasi dan sumber penting untuk kampanye yang berpengaruh (Hornik, Ofir, \& Rachamim, 2016). Penyelenggara kampanye harus memiliki strategi pesan yang tepat agar kampanye ini dapat berhasil.

Strong emotional appeals can have the advantage ofbeingmemorable and contributing to the appreciation of their source. Yet, memorability does not necessarily indicate persuasiveness or actual behavior change (Daya tarik emosional yang kuat bisa memberikan keuntungan karena mudah diingat dan memberikan kontribusi apresiasi pada sumber. Ingatan tidak selalu menunjukkan indikator persuasi telah berhasil atau perubahan perilaku yang sebenarnya) (Perloff, 2017).

Tim Kampanye "Awas KBGO!" menyatakan bahwa kampanye ini ingin memberikan peringatan namun tidak demikian dengan target audiens. Target audiens berpendapat pesanpesan kampanye hanya cenderung informatif dan kurang menyentuh emosi. Penggunaan pesan yang edukatif dan informatif dapat dilakukan jika organisasi ingin membangun opini publik yang positif (Kholisoh, 2015).
Peneliti memandang bahwa Sub Divisi Digital At-Risks sebagai Tim Kampanye "Awas KBGO!" belum dapat mengidentifikasi karakteristik target audiens dengan tepat sehingga maksud pesan kampanye belum dapat diterima dengan baik. Penyelenggara kampanye yang berkaitan dengan isu gender seperti "Awas KBGO!" tidak dapat mengesampingkan fakta bahwa target audiens kampanye ini berasal dari berbagaimacamgenderpula.Perempuanmemiliki respon yang berbeda dibandingkan dengan laki-laki terhadap emotional message appeals (pesan dengan daya tarik emosi). Perempuan cenderung lebih tertarik pada pesan emotional message appeals dibandingkan laki-laki (Hornik et al., 2016; Noble, Pomering, \& Johnson, 2014).

Adapun penelitian sebelumnya berfokus pada efektivitas penggunaan fear appeals dalam kampanye kesehatan, seperti kampanye "The Real Cost" di Amerika untuk pencegahan tembakau (Zhao, Roditis, \& Alexander, 2019) dan kampanye vaksinasi HPV (Avery \& Park, 2018). Di Indonesia, penelitian dilakukan pada kampanye rokok dalam iklan layanan masyarakat (Eriyanto \& Zarkasi, 2017), penerapan Komunikasi Informasi Edukasi (KIE) Vasektomi (Basuki \& Ashrianto, 2020),

Beberapa penelitian tentang penggunaan message appeals juga pernah dilakukan dalam kampanye sosial yang bertemakan kampanye keselamatan berlalu lintas. (Berto, 2015) meneliti efektivitas penggunaan pendekatan rasa takut dalam pesan kampanye keselamatan jalan di Indonesia yang ditujukan pada kalangan usia muda dan hasilnya menunjukkan bahwa perbedaan karakteristik individu menjadi tantangan kampanye. (Guttman, 2015) menemukan bahwa kampanye komunikasi berlalu lintas lebih efektif dengan komunikasi persuasif. Ia juga mengkategorisasikan daya tarik pesan persuasi yang digunakan dalam kampanye keselamatan berlalu lintas dari 300 kampanye yang diperoleh dari 41 negara.

Penelitian mengenai penggunaan daya tarik pesan dalam kampanye sosial yang bertema gender belum banyak dilakukan di Indonesia. Padahal kampanye bertema gender 
Tabel 1. Daftar Informan Penelitian

\begin{tabular}{|c|c|c|c|}
\hline No & Nama & Jabatan & Keterangan \\
\hline 1 & Ellen Kusuma & $\begin{array}{l}\text { Kepala Sub Divisi Digital At-Risks Southeast } \\
\text { Asia Freedom of Network (SAFEnet) dan } \\
\text { Spokesperson Kampanye "Awas KBGO!" }\end{array}$ & Informan Kunci \\
\hline 2 & Nenden Sekar Arum & $\begin{array}{l}\text { Anggota Sub Divisi Digital At-Risks } \\
\text { Southeast Asia Freedom of Network } \\
\text { (SAFEnet) dan Spokesperson Kampanye } \\
\text { "Awas KBGO!" }\end{array}$ & Informan Kunci \\
\hline 3 & Christina Yulita & $\begin{array}{l}\text { Koordinator Divisi Partisipasi Masyarakat } \\
\text { Komisioner Komisi Nasional Anti Kekerasan } \\
\text { Terhadap Perempuan (Komnas Perempuan) }\end{array}$ & Informan Kunci \\
\hline 4 & $\mathrm{~N}$ & Target Audiens Kampanye “Awas KBGO!” & Informan \\
\hline 5 & $\begin{array}{l}\text { Dr. Emilia Bassar, } \\
\text { S.Sos., M.Si., IAPR }\end{array}$ & $\begin{array}{l}\text { Praktisi Kampanye Komunikasi dan Public } \\
\text { Relations dari CPROCOM }\end{array}$ & Triangulator \\
\hline
\end{tabular}

Sumber: Hasil Penelitian (2020)

di Indonesia telah banyak dilakukan tetapi belum dapat dikatakan berhasil mengubah perilaku masyarakat yang kental dengan budaya patriarki. Pembahasan tentang kampanye sosial bertema gender yang dilakukan oleh organisasi nirlaba dan memiliki tujuan untuk perubahan pada tataran individu serta membawa perubahan sosial juga masih sedikit. Kampanye "Awas KBGO!" juga memiliki tantangannya tersendiri karena tidak dapat dilepaskan dari isu feminis. Isu feminis sudah mendapat stigma di Indonesia.

Meski kampanye anti kekerasan juga sudah masif dilakukan oleh berbagai organisasi baik offline dan online, kenyataannya kampanye yang dilakukan masih belum dapat dikatakan berhasil meningkatkan awareness publik terkait isu ini. Pesan yang dikampanyekan dalam "Awas KBGO!" pun diakui oleh SAFEnet sebagai isu yang sensitif dan kampanye ini juga dihadapkan dengan budaya patriarki yang sudah mengakar di Indonesia. Penelitian ini diharapkan dapat menjadi referensi bagi peneliti lain yang ingin membahas tentang kampanye anti kekerasan berbasis gender online. Meski sampai dengan saat ini korban yang paling rentan adalah perempuan dan minoritas gender lainnya (transpuan dan transpria). Penelitian bertujuan untuk menganalisis penggunaan message appeals dalam pesan kampanye "Awas KBGO!" yang dilakukan oleh organisasi nirlaba SAFEnet.

\section{Metode Penelitian}

Metode yang digunakan dalam penelitian ini adalah studi kasus pada organisasi nirlaba SAFEnet. Penelitian ini mencoba untuk mengeksplorasi kasus secara mendalam melalui pengumpulan data yang detail serta menjawab pertanyaan "bagaimana" dan "mengapa", serta pada tingkat tertentu menjawab pertanyaan "apa" (Creswell, 2007; Yin, 2014). Adapun informan dalam penelitian ini tersaji dalam Tabel 1 .

Penelitian ini termasuk dalam studi kasus eksploratori (Creswell, 2007). Peneliti mencoba untuk menguraikan kampanye anti kekerasan berbasis gender online "Awas KBGO!" yang dilakukan oleh organisasi nirlaba SAFEnet.

Pengumpulan data dilakukan dengan wawancara kepada para informan, observasi, dan studi pustaka (Creswell, 2007; Yin, 2014).

Data yang terkumpul kemudian dianalisis dengan analisis model interaktif Miles dan Huberman yang meliputi reduksi data, penyajian data, penarikan kesimpulan serta verifikasi (Miles, Huberman, \& Saldana, 2014). 
Hasil Penelitian dan Pembahasan

"Awas KBGO!" sebagai Pesan Kunci Kampanye

Kampanye pada dasarnya adalah pertukaran pesan atau penyampaian pesan antara pembuat pesan kepada penerima pesan. Pesan kampanye adalah hal yang utama karena kampanye dapat dikatakan berhasil jika target audiens memahami pesan yang disampaikan oleh penyelenggara kampanye.

Kampanye anti kekerasan berbasis gender online yang dilakukan oleh Sub Divisi Digital At-Risks SAFEnet diberi nama "Awas KBGO!". "Awas KBGO!" menjadi judul kampanye sekaligus pesan kunci yang ingin disampaikan oleh Sub Divisi Digital At-Risks selaku penyelenggara kampanye. Melalui pesan ini, penyelenggara kampanye ingin memberikan peringatan (warning) kepada masyarakat bahwa siapapun dapat menjadi korban Kekerasan Berbasis Gender Online (KBGO). Nenden Sekar Arum menerangkan bahwa Sub Divisi Digital At-Risks memilih kata "Awas" dalam kampanye ini untuk menarik perhatian dari masyarakat agar sadar tentang adanya kekerasan berbasis gender online ini dan berhati-hati dalam dunia digital (Wawancara dengan Nenden Sekar Arum, 4 Juni 2020)

Hasil wawancara dengan Nenden Sekar Arum menjelaskan bahwa awal dari penamaan kampanye "Awas KBGO!" yang juga difungsikan sebagai pesan kunci. Pesan kunci yang ingin disampaikan adalah "Awas Kekerasan Berbasis Gender Online". Peneliti memandang penggunaan kata "Awas" ini sesuai dengan maksud dari penyelenggara kampanye yang ingin memberikan peringatan kepada target audiens. Kemudian diikuti dengan kata "KBGO" yang merupakan kepanjangan dari kekerasan berbasis gender online. Dengan kata lain, maksud dari pesan kunci yang ingin disampaikan melalui Kampanye "Awas KBGO!" adalah ingin memberi peringatan kepada publik untuk segera menyadari kekerasan berbasis gender online yang semakin marak.
Selaras dengan Nenden, Ellen juga menyatakan bahwa penamaan "Awas KBGO!" berkaitan dengan maksud atau tujuan dari kampanye ini yaitu seruan untuk publik agar mawas diri dengan keberadaan Kekerasan Berbasis Gender Online (KBGO) (Wawancara dengan Ellen Kusuma, 11 Agustus 2020)

Istilah Kekerasan Berbasis Gender Online atau KBGO adalah istilah baru yang dibuat oleh Sub Divisi Digital At-Risks. Pertama kali istilah ini diperkenalkan oleh SAFEnet kepada masyarakat Indonesia pada akhir Januari 2019 saat konferensi pers SAFEnet peluncuran Buku Panduan untuk Memahami Kekerasan Berbasis Gender Online (KBGO). Istilah ini kemudian diikuti oleh organisasiorganisasi lain termasuk Komnas Perempuan.

Penggunaan kata "Awas" dalam pesan kunci "Awas KBGO!" memberi kesan ingin menghimbau dengan menakut-nakuti. Kesan yang ingin ditampilkan dalam pesan ini masuk dalam konsep yang diperkenalkan oleh Kim Witte. Himbauan menakut-nakuti (fear appeals) pada dasarnya merupakan pesan persuasif yang didesain untuk menakuti khalayak dengan menggambarkan hal-hal buruk yang terjadi pada khalayak bila tidak menuruti perintah yang dilakukan (Venus, 2018). Pesan ini biasanya menggunakan bahasa yang hidup, personal, dan mengandung muatan informasi yang menarik dengan berbagai detailnya.

Pesan menakut-nakuti memiliki efek dalam mengubah perilaku publik, khususnya pesan yang tidak terlalu menakutkan. Pesan ini masih mampu memberikan ancaman serta mampu menunjukkan jalan keluar tentang yang harus dilakukan khalayak (Venus, 2018).

Konteks Kampanye "Awas KBGO!" memiliki karakteristik dari target audiens primer menjadi acuan untuk merancang pesan kampanye. Hal dikarenakan target audiens primer dari Kampanye "Awas KBGO!" adalah usia 1835 tahun yang aktif menggunakan internet dan media sosial. Pesan kampanye yang disampaikan perlu disesuaikan dengan karakteristik rentang usia tersebut dalam menggunakan internet dan bermedia sosial. Penyelenggara kampanye "Awas 


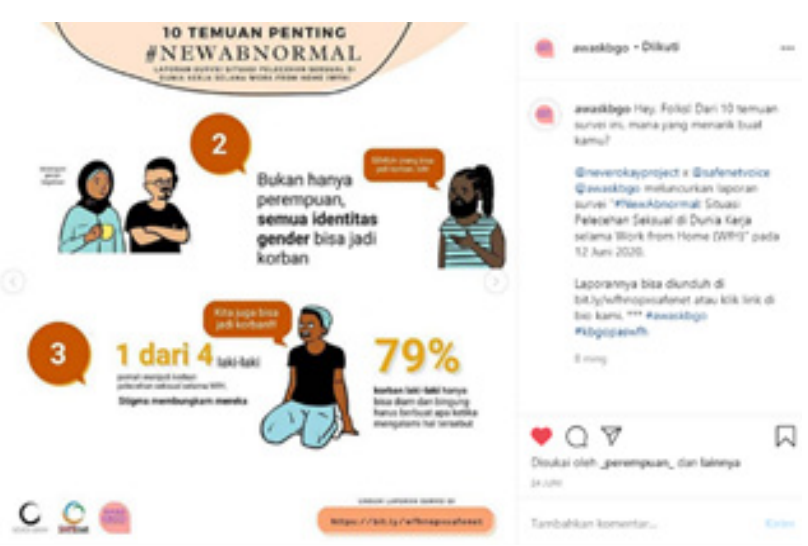

Gambar 1. Hasil Survei Pelecehan Seksual di Dunia Kerja Selama Work from Home (WfH) Sumber: Twitter (2020)

KBGO!" berusaha untuk semenarik mungkin dan menyesuaikan target audiens. Upaya penyebaran pesan kampanye melalui media online, Sub Divisi Digital At-Risks menyesuaikan pesan dan menggunakan semaksimal mungkin fitur yang ada dalam media tersebut. Nenden (Wawancara dengan Nenden Sekar Arum, 4 Juni 2020) menyatakan bahwa Sub Divisi Digital At-Risks berusaha agar pesan yang disampaikan dalam Kampanye "Awas KBGO!" menggunakan istilah yang sederhana disesuaikan dengan target audiens primer kampanye agar mudah dipahami.

\section{Penggunaan Daya Tarik Pesan (Message Appeals) dalam Kampanye "Awas KBGO!"}

Penggunaan reasoning appeals (daya tarik alasan) berkaitan dengan penggunaan data, analogi, dan simulasi dalam penyampaian pesan kampanye. Pesan-pesan Kampanye "Awas KBGO!" menggunakan data untuk memberikan pesan yang informatif kepada target audiens. Penggunaan data lebih banyak digunakan dalam pesan yang disampaikan melalui kampanye online. Contohnya adalah pengungkapan temuan hasil dari survei pelecehan seksual di dunia kerja survei pelecehan kerja selama work from home ( $w f h$ ) seperti yang terlihat pada Gambar 1.

Penggunaan analogi dan simulasi lebih banyak digunakan dalam pesan kampanye yang disampaikan secara offline oleh Spokesperson. Spokesperson dari Kampanye "Awas KBGO!"

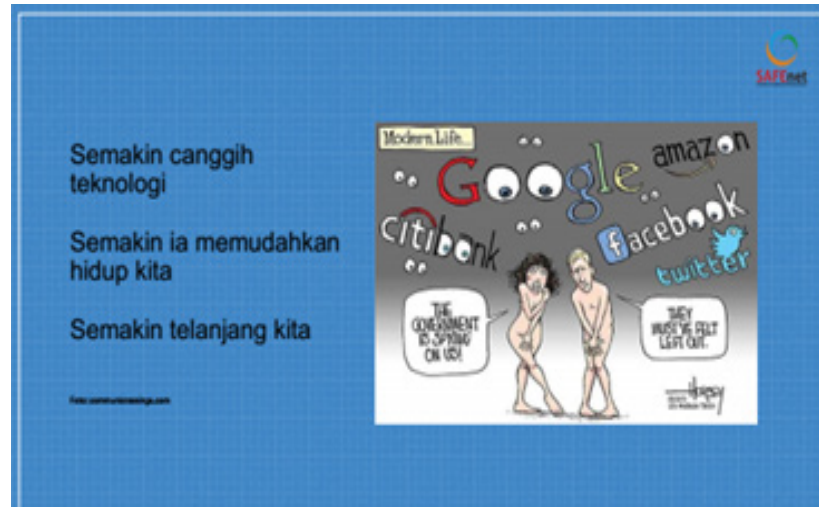

Gambar 2. Slide Presentasi yang Digunakan dalam Kampanye Offline

Sumber: Hasil Penelitian (2020)

menyadari penggunaan analogi dan simulasi dapat mempermudah audiens untuk memahami informasi yang disampaikan. Seperti pada saat spokesperson menjelaskan tentang pengetahuan dasar keamanan digital. Spokesperson menggunakan kata "telanjang" sebagai simbol dari semakin terbukanya informasi tentang pengguna di dunia digital (Gambar 2). Pernyataannya adalah sebagai berikut, "Semakin canggih teknologi, semakin Ia memudahkan hidup kita, semakin telanjang pula kita."

Analogi lain yang disampaikan pada kampanye offline adalah analogi untuk memberikan gambaran kepada audiens tentang data pribadi yang boleh dibagikan dan tidak dibagikan di dunia digital. Spokesperson menggunakan analogi "KTP (Kartu Tanda Penduduk) yang ditempel di angkot". Analogi ini dimaksudkan agar target audiens dapat membayangkan dengan mudah peristiwa KTP yang memuat data pribadi didalamnya dan dengan setting angkot. Diakui oleh Ellen Kusuma, sulit bagi target audiens untuk memahami tentang sesuatu boleh disebarkan atau tidak di dunia digital. Oleh karena itu, dengan analogi "KTP yang ditempel di angkot" audiens diharapkan lebih dapat memahami.

Spokesperson menggunakan analogi tersebut karena hal tersebut dianggap peristiwa yang bisa dibayangkan semua. Ide dari analogi ini adalah berdasarkan pengalaman pribadi 
dari Spokesperson yang sering melihat banyak tempelan di angkot. Ellen beranggapan bahwa setting di angkot adalah yang paling common dan orang lain bisa membayangkannya jika KTP ditempel di angkot. (Wawancara dengan Ellen Kusuma, 11 Agustus 2020)

Adapun untuk simulasi digunakan dalam kampanye offline dan disampaikan oleh Spokesperson. Salah satu simulasi dilakukan untuk menyadarkan audiens bahwa terdapat fitur di gawai yang dapat membuat jejak digital abadi. Simulasi ini tidak langsung dilakukan saat ada instruksi diawal paparan, tetapi dilakukan pada akhir paparan. Simulasi baru dilakukan pada akhir pemaparan sebelum menutup pemaparan. Pertanyaan Spokesperson pada saat awal pemaparan adalah "Rata-rata butuh sama atau kurang dari 5 klik untuk share sebuah konten. Ada 2 fitur sederhana nan abadi di handphone yang bikin konten kamu dari privat jadi publik. Fitur apakah itu? Silakan dijawab diakhir nanti." Dalam konteks pesan kampanye, simulasi ini dilakukan agar target audiens dapat lebih memahami, mengingat, dan waspada tentang betapa mudahnya konten yang tadinya privat menjadi publik.

Pesan selalu menggunakan simbol, baik verbal maupun nonverbal, yang diharapkan memancing respons tertentu dari khalayak (Venus, 2018). Applbaum dan Anatol (1986 dalam Venus, 2018) menekankan pentingnya menyadari bahwa kegiatan kampanye mengandalkan pesanpesan simbolik. Melalui perantara simbol, pesan-pesan kampanye dirancang secara persuasif, kreatif, dan sistematis agar dapat memunculkan respons tertentu pada pikiran khalayak. Agar respons tersebut muncul, perlu adanya kesamaan pengertian tentang simbolsimbol yang digunakan diantara perencana/ pelaku kampanye dan penerima. Oleh karena itu, menciptakan kesamaan makna (commonness) antara perencana atau pelaku kampanye dan penerima pesan adalah dasar tercapainya tujuan kampanye yang bersifat persuasif. Kesamaan makna antara spokesperson dan target audiens adalah karena analogi yang digunakan sebagai contoh sangat dekat dengan kehidupan sehari-hari target audiens. Spokesperson mencari analogi yang hampir dialami oleh semua orang dan spokesperson juga mengalami. Pengalaman spokesperson dalam keseharian penting untuk dapat menjadi inspirasi dalam memberikan analogi kepada target audiens.

Tim Kampanye "Awas KBGO!" juga senantiasa berhati-hati dalam pemilihan kata yang digunakan dalam pesan kampanye. Kehati-hatian menjadi salah satu aspek yang paling diperhatikan dalam strategi pesan pada Kampanye "Awas KBGO!" Terlebih SAFEnet selalu memegang prinsip untuk berperspektif korban (berpihak pada korban) dalam penyampaian pesannya. Dengan kata lain, Sub Divisi Digital At-Risks memilah dan memilih kata-kata yang paling pantas sebagai pesan kampanye agar dapat menyampaikan pesan secara benar dan tidak menyakiti pihak manapun.

Berkaitan dengan Kekerasan Berbasis Gender Online (KBGO), banyak kosa kata baru tentang yang menggunakan Bahasa Inggris. Sub Divisi Digital At-Risks pun harus mencari padanan kata yang tepat dan mendeskripsikannya secara singkat dan padat dalam Bahasa Indonesia.

Nenden Sekar Arum sebagai Anggota Sub Divisi Digital At-Risks menjelaskan bahwa dalam penyampaian pesan kampanye "Awas KBGO!", SAFEnet ingin menyampaikan hal yang benar dan berperspektif korban sehingga tidak menjadikan korban dua kali dan tidak menyakiti pihak manapun. "Gini, kalau terkait dengan isu-isu perempuan dan isu-isu yang sensitif itu, itu ya memang akhirnya nggak cuman Ilmu Komunikasi aja yang dipakai. Tapi bagaimana perspektif korban itu sangat penting. Jadi, kita bukan hanya amplify isu tapi bagaimana kita bisa menyampaikan isu itu dengan benar, baik, dan tidak menyakiti atau membuat korban menjadi korban dua kali." (Nenden Sekar Arum, 4 Juni 2020) Kehati-hatian dalam pemilihan kata dalam Kampanye "Awas KBGO!" ini berdasarkan pengalaman mereka sebagai relawan SAFEnet. Sebelum akhirnya ada Sub Divisi Digital AtRisks dan mengadakan kampanye ini, mereka 
Tabel 2. Penggunaan Reasoning Appeals (Daya Tarik dengan Alasan) dengan Menggunakan Data, Analogi, dan Simulasi

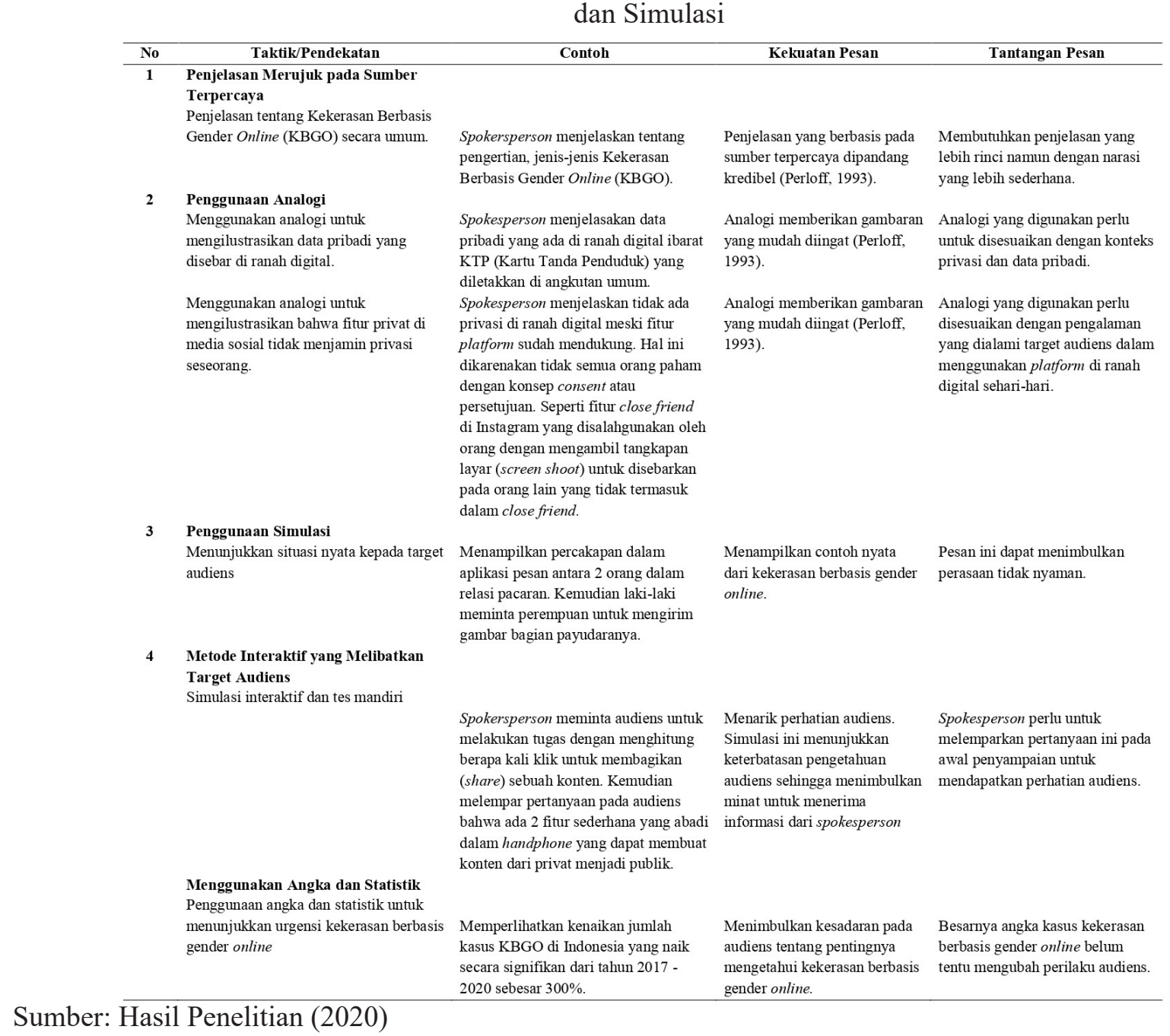

Sumber: Hasil Penelitian (2020)

sudah terlebih dahulu banyak terlibat dalam penanganan kasus kekerasan siber dan kekerasan berbasis gender online. Dengan kata lain, penyelenggara kampanye "Awas KBGO!" adalah praktisi kampanye sosial. Sayangnya, Sub Divisi Digital At-Risks melakukan perencanaan hingga evaluasi kampanye tanpa mempelajari lebih jauh mengenai kampanye komunikasi ataupun meminta saran dari para ahli komunikasi kampanye sosial. Meski demikian, kampanye yang baru diadakan pada November 2019 ini tetap berjalan dan mendapat respon yang cukup baik dari target audiens kampanye.
Salah satu upaya yang dilakukan SAFEnet yang mencerminkan kehati-hatian dalam pemilihan kata dan berperspektif gender adalah penggunaan istilah "penyebaran konten intim tanpa persetujuan" sebagai pengganti istilah revenge porn.

Ellen bersama dengan Sub Divisi Digital At-Risks memaknai istilah revenge porn sebagai istilah yang problematik dan menyalahkan korban. Istilah revenge porn cenderung melihat korban sebagai pihak yang salah. Dalam istilah ini ada upaya dari pelaku untuk balas dendam kepada korban karena korban telah berbuat salah kepada pelaku. 
Tabel 3. Penggunaan Appeals to Negative Emotions (Daya Tarik yang Menimbulkan Emosi Negatif)

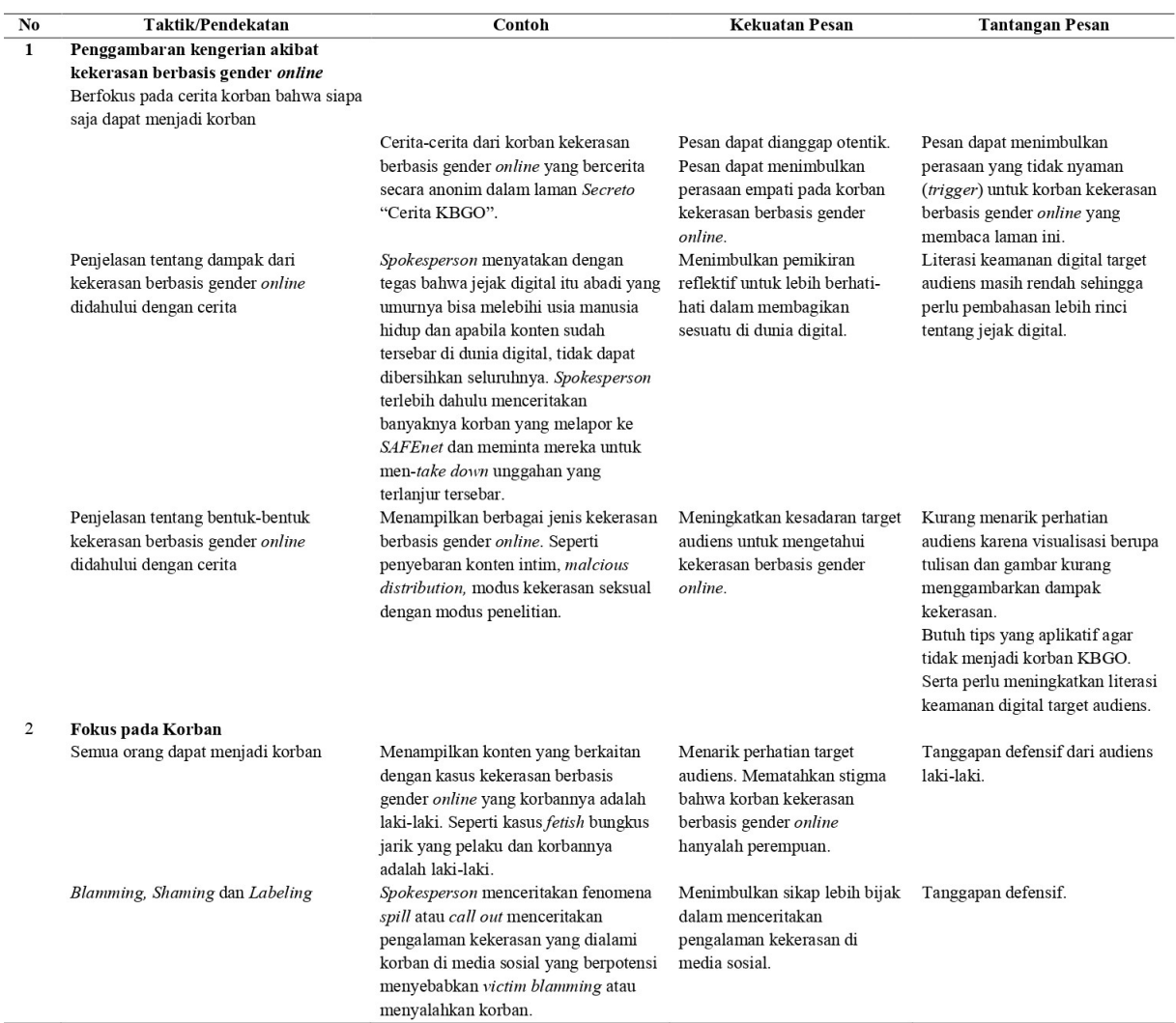

Sumber: Hasil Penelitian (2020)

menyebabkan victim blamming atau

Dalam setiap kesempatan, Spokesperson kampanye konsisten menyampaikan pesan bahwa penggunaan istilah "revenge porn" tidak tepat. "Sebenarnyakami kurang suka menggunakan kata 'revenge porn' karena problematik ya. Revenge itu kan balas dendam artinya dan porn itu adalah pornografi. Revenge itu seakan-akan pelaku berhak melakukan hal ini karena si korban sudah salah duluan ke dia (pelaku). Jadi, si pelaku mengancam korban ini untuk balas dendam gitu. Jadi, seakanakan posisi korban sudah salah dulu, gitu. Dan kata porn atau pornography lebih identik dengan konten-konten hiburan dalam artian entertainment. Kita tidak bisa memungkiri hal itu bahwa porn is part of an entertainment industry. Nah disitu menurut saya problemnya adalah porn ini sendiri adalah industri entertainment atau industri hiburan. Itu seakan-akan yang namanya konten intim itu ya pornografi. Padahal konten intim yang barangkali diserahkan oleh korban kepada pelaku baik consented maupun nonconsented itu sendiri adalah konten yang bukan ditujukkan untuk dunia hiburan. Itu hanya ditujukkan untuk pasangannya. Mereka sedang berada dalam relasi intim. Jadi, kata revenge porn ini memang problematik kalau bagi kami walaupun kami masih tetap menggunakannya... (Pernyataan Ellen Kusuma dalam Seminar Daring Magdalene Learning Club "Digital Safety 101" pada Selasa, 28 Juli 2020) Peneliti merangkum penggunaan reasoning appeals (daya tarik dengan alasan) dengan Menggunakan Data, Analogi, dan Simulasi pada Tabel 2.

Penggunaan Daya TarikEmosional(Emotional Appeals) dalam Kampanye "Awas KBGO!" Penggunaan Appeals to Negative Emotions (DayaTarikyangMenimbulkanEmosiNegatif)

Penggunaan daya tarik pesan yang menimbulkan perasaan negatif yaitu: (1) Penggambaran kengerian akibat kekerasan berbasis gender online dengan berfokus pada 
cerita korban bahwa siapa saja dapat menjadi korban serta bentuk dan dampak KBGO; (2) Fokus pada pengalaman yang dialami oleh korban seperti blamming, shaming, dan labeling.

Salah satu contoh pesan yang menimbulkan perasaan negatif adalah unggahan utas (thread) di Twitter tentang kasus fetish bungkus jarik yang korbannya adalah laki-laki. Utas ini bertuliskan, "Hati-hati dengan modus KBGO berkedok penelitian, tweeps!-utas 1/3 -" Utas ini mendapat engagements tertinggi dalam kampanye "Awas KBGO!" di Twitter dengan rata-rata engagements 11.003. Fitur utas (thread) memudahkan pengguna Twitter untuk menyampaikan pesan panjang dengan lebih sistematis. Utas ini dibuat sebagai bentuk sikap dari Tim Kampanye "Awas KBGO!" untuk semakin menyadarkan masyarakat bahwa kekerasan berbasis gender online bisa menyerang gender apapun termasuk laki-laki dengan cara-cara yang tidak disadari.

Ellen Kusuma menjelaskan alasan SAFEnet akhirnya membuat unggahan tersebut, "Karena modus tersebut tidak hanya baru itu saja dari hasil pantauan kami. Sudah beberapa kali terjadi dan kami putuskan untuk membuatnya." (Wawancara dengan Ellen Kusuma, 11 Agustus 2020)

Kasus Kekerasan Berbasis Gender Online (KBGO) dengan modus penelitian yang lebih dikenal dengan kasus fetish bungkus kain jarik dilakukan oleh Gilang, mahasiswa Fakultas Ilmu Budaya Universitas Airlangga Surabaya. Kasus ini sempat menjadi perbincangan dan trending topic di Twitter. Gilang melakukan Kekerasan Berbasis Gender Online (KBGO) dengan meminta data pribadi korbannya seperti nomor handphone, foto, dan video sesuai permintaannya dengan berkedok penelitian. Hal ini menjadi perbincangan di Twitter dikarenakan korban dari Gilang membuat utas (thread) tentang pengalaman Kekerasan Berbasis Gender Online (KBGO) yang dialaminya.

Saat kasus tersebut ramai diperbincangkan, Sub Divisi Digital At-Risks mengambil momentum dengan membuat utas. Peneliti memandang langkah tersebut sangat tepat karena dalam menyampaikan pesan kampanye tentang Kekerasan Berbasis GenderOnline (KBGO) perlu adanya strategi pesan yang menyentuh emosi audiens. Kemudian agar pesan kampanye yang sampaikan dapat disadari, dipahami, dan diingat oleh target audiens adalah dengan mengambil momen terjadinya kasus yang sedang hangat diperbincangkan di media sosial seperti ini.

Dalam utas tersebut, Tim Kampanye "Awas KBGO!" ingin masyarakat lebih berhati-hati dengan modus operandi baru dalam kekerasan berbasis gender online yaitu mengumpulkan data pribadi berkedok penelitian. Pesan disampaikan dengan menggunakan fitur utas (thread) dari Twitter karena pesan memang harus dipisah untuk mempermudah pemahaman. Tim "Awas KBGO!" membaginya menjadi tiga, yaitu pesan himbauan, informasi, dan tips agar tidak menjadi korban. Pada unggahan terakhir diberi tautan link menuju Buku Panduan tentang Memahami Kekerasan Berbasis Gender Online yang telah dibuat oleh Sub Divisi Digital At-Risks SAFEnet.

Utas ini dibuka dengan sebuah gambar yang didalamnya ada penggunaan simbol segitiga yang ada tanda seru didalamnya, kemudian ada katakata "Halo, salam kenal. Saya dari Universitas Ternama dan sedang melakukan penelitian, boleh nggak minta nomor hape kamu, foto tubuh kamu, video kamu..." dan ditutup dengan tulisan berwarna merah "Hati-Hati Ini Modus!"

Tim "Awas KBGO!" memberikan pesan agar masyarakat berhati-hati dan menghimbau untuk tidak sembarangan menyerahkan data pribadi pada pelaku yang menggunakan modus penelitian. Utas ini dilengkapi dengan gambar yang menjelaskan tentang modus kekerasan berbasis gender online yang mengumpulkan data pribadi calon korban dengan mengatasnamakan diri sebagai mahasiswa yang melakukan penelitian. Data pribadi tersebut mulai dari foto atau video, nomor handphone, hingga nomor rekening karena diiming-imingi dengan uang. Jika data pribadi ini digunakan secara tidak bertanggung jawab, maka berpotensi pada kekerasan online dan kekerasan berbasis gender online. Selain itu, unggahan ini juga dilengkapi dengan hashtags \#HatiHatilniModus. Peneliti merangkum penggunaan daya tarik pesan yang menimbulkan emosi negatif (appeals to negative emotions) pada Tabel 3. 
Tabel 4. Penggunaan Appeals to Postive Emotions (Daya Tarik yang Menimbulkan Emosi Positif)

\begin{tabular}{|c|c|c|c|c|}
\hline No & Taktik/Pendekatan & Contoh & Kekuatan Pesan & Tantangan Pesan \\
\hline 1 & $\begin{array}{l}\text { Berempati kepada } \\
\text { Korban } \\
\text { Berfokus pada cerita } \\
\text { korban kekerasan } \\
\text { berbasis gender online }\end{array}$ & $\begin{array}{l}\text { Cerita-cerita dari korban } \\
\text { kekerasan berbasis } \\
\text { gender online yang } \\
\text { bercerita secara anonim } \\
\text { dalam laman Secreto } \\
\text { "Cerita KBGO" yang } \\
\text { mendapat tanggapan dari } \\
\text { korban lainnya dan } \\
\text { saling menyemangati }\end{array}$ & $\begin{array}{l}\text { Pesan yang } \\
\text { menyentuh emosi } \\
\text { dapat dianggap } \\
\text { kredibel dan otentik } \\
\text { (Perloff, 1993). } \\
\text { Mengajak target } \\
\text { audiens untuk } \\
\text { berperspektif } \\
\text { korban dan tidak } \\
\text { menyalahkan } \\
\text { korban. }\end{array}$ & $\begin{array}{l}\text { Pesan dapat } \\
\text { menimbulkan } \\
\text { perasaan yang tidak } \\
\text { nyaman (trigger) } \\
\text { untuk korban } \\
\text { kekerasan berbasis } \\
\text { gender online yang } \\
\text { membaca laman ini. }\end{array}$ \\
\hline 2 & $\begin{array}{l}\text { Tindakan Kolektif } \\
\text { Bersama dengan Mitra } \\
\text { SAFEnet } \\
\text { mengkampanyekan anti } \\
\text { kekerasan berbasis } \\
\text { gender online }\end{array}$ & $\begin{array}{l}\text { Menunjukkan } \\
\text { organisasi, gerakan, dan } \\
\text { lembaga yang } \\
\text { menyuarakan tentang } \\
\text { anti kekerasan berbasis } \\
\text { gender online. Seperti } \\
\text { Never Okay Project } \\
\text { sebagai inisiatif untuk } \\
\text { pelecehan di tempat } \\
\text { kerja, Magdalene } \\
\text { sebagai media feminis, } \\
\text { Lembaga Bantuan } \\
\text { Hukum APIK Jakarta } \\
\text { yang menjadi rujukan } \\
\text { kasus kekerasan berbasis } \\
\text { gender online, dan } \\
\text { Yayasan Pulih sebagai } \\
\text { lembaga pendampingan } \\
\text { psikologis khusus untuk } \\
\text { korban kekerasan. }\end{array}$ & $\begin{array}{l}\text { Membantu } \\
\text { menciptakan dan } \\
\text { memperkuat norma } \\
\text { tanggung jawab } \\
\text { kolektif }\end{array}$ & $\begin{array}{l}\text { Target audiens tidak } \\
\text { tertarik dengan isu } \\
\text { yang disampaikan. }\end{array}$ \\
\hline
\end{tabular}

Sumber: Hasil Penelitian (2020)

Penggunaan Appeals to Positive Emotions (Daya Tarik yang Menimbulkan Emosi Positif)

Penggunaan daya tarik pesan yang menimbulkan perasaan positif dilakukan dengan taktik pesan yang berempati kepada korban dan tindakan kolektif. Pesan-pesan yang berempati kepada korban terlihat pada unggahan yang ada di laman Secreto "Cerita KBGO". Laman ini bertujuan sebagai tempat bercerita yang aman bagi korban kekerasan berbasis gender online sehingga korban tidak merasa sendirian dalam menghadapi kekerasan ini. Tim kampanye "Awas KBGO!" mencoba membangun komunikasi yang berperspektif korban dan tanpa penghakiman kepada korban yang telah bercerita. Pesan yang disampaikan melalui kolom reply merupakan bentuk komunikasi positif yang berarti bagi korban kekerasan berbasis gender online.

Contoh lain adalah pernyataan sikap SAFEnet terkait kasus yang menimpa seorang aktris Tara Basro. Tara mengunggah foto dirinya dalam media sosial Instagram untuk mengkampanyekan tentang body positivity. Unggahan tersebut dianggap melanggar Undang-Undang ITE pasal Kesusilaan oleh Kementerian Komunikasi dan Informatika Republik Indonesia. SAFEnet kemudian mengkritik sikap Kementerian Kominfo karena penggunaan pasal karet Undang-Undang ITE dan membatasi kebebasan berekspresi perempuan.

Adapun tindakan kolektif dilakukan bersama dengan Mitra SAFEnet. Kampanye sosial seperti “Awas KBGO!" tidak dapat dilakukan sendirian, Meski belum ada ajakan kerjasama secara formal, berbagai stakeholder sudah ikut mengedukasi masyarakat tentang KBGO. Diantaranya adalah Lembaga Pemerintah (Komnas Perempuan, Kementerian Pemberdayaan Perempuan dan Perlindungan Anak), Civil Society Organization (Never Okay Project, Yayasan Pulih, Jakarta Feminist, Hope Helps Universitas Indonesia, Samahita Bandung, serta jaringan gerakan perempuan lainnya), Lembaga Bantuan Hukum 
Tabel 5. Sepuluh Tweets dengan Engagement Tertinggi pada Periode November 2019 hingga Agustus 2020

\begin{tabular}{|c|c|c|c|c|}
\hline No & Tweet & Foto/Video Penunjang & Engagement & $\begin{array}{c}\text { Strategi Pesan yang } \\
\text { Digunakan }\end{array}$ \\
\hline 1 & $\begin{array}{l}\text { Hati-hati dengan modus KBGO berkedok penelitian, tweeps! } \\
\text { - utas } 1 / 3 \text { - }\end{array}$ & A & 11.003 & $\begin{array}{l}\text { Daya tarik dengan menakut- } \\
\text { nakuti (fear appeals) }\end{array}$ \\
\hline 2 & $\begin{array}{l}\text { Tweeps, bila menemukan konten yang mengandung kekerasan seksual dan tidak } \\
\text { merahasiakan identitas korban, STOP DI KAMU. } \\
\text { Jangan di-share atau diposting ulang, terutama yang masih menampilkan identitas } \\
\text { korban. }\end{array}$ & STOP DI & 4.444 & $\begin{array}{l}\text { Daya tarik dengan menakut- } \\
\text { nakuti (fear appeals) }\end{array}$ \\
\hline 3 & $\begin{array}{l}\text { cc @ KomnasPerempuan } \\
\text { SAFEnet mengecam postingan Dedy Susanto yang menggunakan pasal karet UU } \\
\text { ITE untuk mengintimidasi terduga korban kekera san seksual. }\end{array}$ & $\begin{array}{l}\text { THIS } \\
\text { AIN'T } \\
\text { IT. } \\
\text { DED. }\end{array}$ & 2.899 & $\begin{array}{l}\text { Daya tarik } \\
\text { argumentasi } \\
\text { appeals) }\end{array}$ \\
\hline 4 & $\begin{array}{l}\text { SAFEnet Mengkritik @kemkominfo Atas Pelabelan Pornografi Pada Unggahan } \\
\text { Body Positivity @TaraBasro } \\
\text { Lagi, dan lagi. Pasal karet } 27 \text { Ayat } 1 \text { UU ITE kali ini muncul menghadang } \\
\text { kebebasan berekspresi perempuan. } \\
\text { Selengkapnya di https://t.co/LPf6StfgD }\end{array}$ & 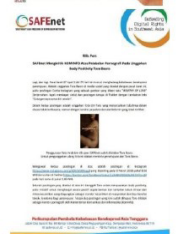 & 1.108 & $\begin{array}{lr}\begin{array}{l}\text { Daya tarik } \\
\text { argumentasi }\end{array} & \begin{array}{r}\text { menggunakan } \\
\text { appeals) }\end{array} \\
\text { (reasoning }\end{array}$ \\
\hline 5 & $\begin{array}{l}\text { Apa sih KBGO aka kekerasan berbasis gender online itu? } \\
\text { \#16HAKTP \#GerakBersama \#awasKBGO }\end{array}$ & 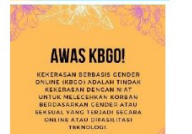 & 630 & $\begin{array}{l}\text { Daya tarik menggunakan data } \\
\text { (reasoning appeals) }\end{array}$ \\
\hline 6 & $\begin{array}{l}\text { Nih, ada } 4 \text { tips supaya kamu bisa lebih aman menyikapi modus KBGO berkedok } \\
\text { penelitian, tweeps! } \\
\text { Stay safe! } \\
\text { Follow kami di Instagram @/awaskbgo ya! }\end{array}$ & 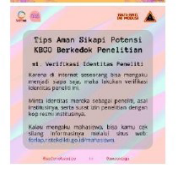 & 314 & $\begin{array}{l}\text { Daya tarik } \\
\text { argumentasi } \\
\text { appeals) }\end{array}$ \\
\hline 7 & $\begin{array}{l}-3 / 3 \text { - } \\
\text { Potret KBGO (kekerasan berbasis gender online) yang terjadi di Indonesia. } \\
\text { Menurut catatan tahunan @KomnasPerempuan trennya meningkat! } \\
\text { \#16HAKTP \#GerakBersama \#AwasKBGO }\end{array}$ & 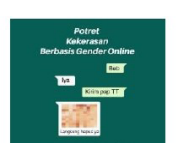 & 299 & $\begin{array}{l}\text { Daya tarik menggunakan data } \\
\text { (reasoning appeals) }\end{array}$ \\
\hline 8 & $\begin{array}{l}\text { Tweeps, pernah menghadapi konten intim disebarkan pelaku? } \\
\text { Simak tipsnya berikut. } \\
\text { \#16HAKTP \#16days \#GerakBersama \#awaskbgo }\end{array}$ & HONIENINII & 217 & $\begin{array}{l}\text { Daya tarik } \\
\text { argumentasi } \\
\text { appeals) }\end{array}$ \\
\hline 9 & $\begin{array}{l}\text { Hey Folks, pelecehan seksual tetap dapat terjadi selama Working from Home } \\
\text { (WFH). } \\
\text { Bantu kami, @neverokayprjct \& @safenetvoice, u/ memetakan \& memutus mata } \\
\text { rantai pelecehan seksual di dunia kerja selama WFH dengan mengisi survei di } \\
\text { https://t.co/UzO8dA3AF1 }\end{array}$ & 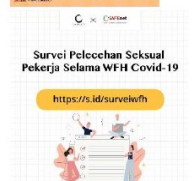 & 164 & $\begin{array}{l}\text { Daya tarik } \\
\text { argumentasi } \\
\text { appeals) }\end{array}$ \\
\hline 10 & $\begin{array}{l}\text { \#HatiHatilniModus } \\
\text { Jangan sembarang menyerahkan data pribadimu pada pelaku yang menggunakan } \\
\text { modus ini, lhoo! } \\
-2 / 3 \text { - }\end{array}$ & 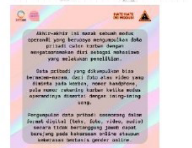 & 138 & $\begin{array}{l}\text { Daya tarik } \\
\text { argumentasi } \\
\text { appeals) }\end{array} \quad \begin{array}{r}\text { (reasonging } \\
\text { (peanakan }\end{array}$ \\
\hline
\end{tabular}

Sumber: Hasil Penelitian (2020)

(LBH APIK Jakarta), Media (Magdalene, Konde), Digital Platform (Google, Facebook, Twitter), dan Digital Influencer (Kalis Mardasih).

Peneliti merangkum penggunaan daya tarik pesan yang menimbulkan emosi positif (appeals to positive emotions) pada Tabel 4.

\section{Implementasi Penggunaan Message Appeals dalam Media Sosial Twitter}

Twitter masih menjadi media sosial yang paling sering digunakan di Indonesia. Hal ini didukung dengan hasil penelitian dari Pew Research Center, yang menyatakan bahwa 
Twitter menjadi platform media sosial tertinggi kelima yang paling sering digunakan oleh masyarakat Indonesia yakni sebesar 56\%. Indonesia menempati peringkat delapan dunia untuk menjangkau 10.000.000 audiens. Meski penggunaan Twitter di Indonesia masih dibawah Instagram, perbincangandi Twittertetapmendapat perhatian dan mempengaruhi alur informasi yang beredar di internet. Peneliti beranggapan bahwa trending topic di Twitter sering menjadi bahan penelitian ilmiah, menjadi tajuk utama media, dan bahan diskusi publik secara offline.

Media sosial Twitter menjadi salah satu media sosial yang digunakan SAFEnet dalam upaya mengkampanyekan anti kekerasan berbasis gender online. Twitter menjadi platform media sosial yang menawarkan pesan ringkas karena unggahan karakter pada Twitter terbatas hanya 280 karakter. Sebagai media sosial yang berkonsep microblogging, Twitter makin berkembang dengan memberikan fitur untuk lebih dapat berinteraksi sesama pengguna Twitter.

SAFEnet membuat akun Twitter @ safenetvoice sejak Juni 2013. Sampai dengan 10 Agustus 2020, pengikut akun Twitter@ safenetvoice telah mencapai 16.784 pengguna dan telah membagikan tweets sebanyak 3.084.

Twitter mengembangkan sejumah fitur untuk meningkatkan pengalaman pengguna Twitter. Sejumlah fitur baru membuat Twitter lebih interaktif dan atraktif. Salah satu diantaranya adalah Twitter memberikan fitur pinned untuk tweetyangmenurut pemilik akun perludibaca oleh pengunjung profil pemilik akun Twitter tersebut dan berada pada beranda profil pemilik akun Twitter. Fitur pinned tweet dapat difungsikan juga sebagai pengingat. Fitur ini pun dimanfaatkan oleh SAFEnet. Sampai dengan Agustus 2020, tweet yang di-pinned dalam halaman profil akun Twitter@safenetvoice adalah mengenai Laporan Tahunan SAFEnet pada tahun 2018. Laporan ini berguna bagi followers dan pengunjung akun yang ingin membaca lebih lengkap tentang halhal yang telah diperjuangkan oleh SAFEnet.
Penyebaran kampanye melalui Twitter dirasa penting bagi SAFEnet karena mengingat pengguna Twitter di Indonesia dan followers Twitter@safenetvoice juga cukup banyak. Peneliti mengamati pesan-pesan yang disebarkan dalam Twitter SAFEnet dan menyimpulkan bahwa SAFEnet menyamakan konsep content plan dengan media sosial Instagram SAFEnet. Disamping itu, laju linimasa (timeline) Twitter juga sangat cepat sehingga penyebaran pesan terkesan sporadis.

Peneliti melihat bahwa SAFEnet pun memiliki audiens sasaran dalam pemakaian media Twitter meski tidak diungkapkan secara langsung. Peneliti berpandangan bahwa melalui media sosial Twitter, SAFEnet mencoba menyasar pengguna yang lebih memilih untuk mencari informasi yang cepat dan singkat. Penggunaan bahasa yang singkat, sederhana, dan mudah dipahami menjadi strategi SAFEnet agar followers akun SAFEnet tertarik untuk membaca pesan tersebut. Melalui Twitter, informasi tersebut disampaikan disertai visual yang mendukung.

Peneliti melakukan analisis terhadap pesanpesan yang diunggah dalam bentuk tweet dan aktivitas yang dilakukan oleh SAFEnet dalam akunTwitter@safenetvoice selama November 2019 hingga Agustus 2020. Dengan bantuan perangkat lunak analisis media sosial bernama Keyhole, peneliti menemukan sejumlah hal yang penting untuk diulas lebih lanjut. Total engagements yang didapatkan dalam akun@ safenetvoice adalah 132.219, dengan rincian rata-rata sebuah unggahan disukai sebanyak 142 dan rata-rata sebuah unggahan di-ReTweets sebanyak 106. Peneliti merangkum 10 tweets tentang Kampanye "Awas KBGO!" dengan engagement tertinggi periode November 2019 hingga Agustus 2020 dalam tabel 5.

Berikutnya, Tim "Awas KBGO!" mencoba untuk menyampaikan pesan yang bersifat informatif dengan memberikan empat tips aman dalam menyikapi modus kekerasan berbasis gender online yang berkedok penelitian. Tips tersebut adalah verifikasi identitas peneliti, verifikasi tujuan penelitian, tidak menyerahkan nomor ponsel, dan hindari tergiur diimingi uang. 
Interaksi yang tercipta dalam Twitter SAFEnet@safenetvoice lebih banyak terjadi antar sesama pengguna Twitter baik itu followers SAFEnet maupun bukan. Sejauh SAFEnet menggunakan Twitter, followers dan pengunjung akun melakukan interaksi dalam kolom reply dan melakukan ReTweets dan berkomentar. Dalam kolom reply yang berkaitan dengan pesan-pesan kampanye "Awas KBGO!", peneliti menemukan bahwa followers dan pengunjung merespon mengenai isu yang sedang dibahas. Peneliti menemukan ada dua respon yakni netral dan negatif.

Respon negatif peneliti temukan pada kolom balasan (reply) tweet yang menghimbau agar masyarakat tidak meneruskan pesan yang bermuatan kekerasan seksual terlebih jika menampilkan identitas korban. Tweet ini juga menautkan akun@KomnasPerempuan. Tweet tersebut kemudian menuai balasan yang bernada negatif dari pengguna Twitter. Salah satunya akun @NUGROS13 yang menuliskan, "Kalau gak viral dulu ya kalian gak kerja". Kemudian @AndriSitumorang yang menuliskan, "Mana ni SJW suaranya?"

Respon negatif oleh pengguna Twitter terhadap pesan yang berkaitan dengan kampanye anti kekerasan berbasis gender online, menguatkan pernyataan dari Nenden Sekar Arum sebagai penyelenggara kampanye. Ia menerangkan bahwa sebelum dibuatnya kampanye "Awas KBGO!", SAFEnet harus siap dengan kelompok yang kontra. Kelompok kontra ini muncul dalam segala hal yang berhubungan dengan kampanye Rancangan Undang-Undang Penghapusan Kekerasan Seksual (RUU PKS). Kampanye "Awas KBGO!" masuk dalam kampanye yang mendukung kampanye besar RUU PKS. (Wawancara dengan Nenden Sekar Arum, 4 Juni 2020)

Sub Divisi Digital At-Risks memang mengakui bahwa mereka hanya fokus pada media sosial Instagram untuk penyebaran pesan kampanye "Awas KBGO!". Peneliti melakukan pengamatan pada unggahan yang berkaitan dengan kampanye anti kekerasan berbasis gender online pada akun SAFEnet sejak November tahun 2019 lalu. Peneliti menyimpulkan bahwa Sub Divisi Digital At-Risks memang fokus mengemas pesan kampanye dalam bentuk gambar karena prioritas pengunggahan ada pada Instagram. Barulah setelah itu akun media sosial lain seperti Twitter sehinga di Twitter pun banyak unggahan gambar. Sebaiknya SAFEnet dapat memanfaatkan media sosial Twitter untuk merangkaikata, bukan hanya sebagai media untuk menyebarkan pesan bergambar. Hal ini berdasar dari analisis Twitter yang peneliti lakukan melalui social media analytics Keyhole bahwa engagements tertinggi adalah unggahan teks.

Berdasarkan hasil analisis Keyhole social media analytics dapat disimpulkan bahwa SAFEnet lebih banyak melakukan aktivitas interaksi seperti membalas pesan (reply) dan Retweet. Sedangkan aktivitas yang paling tinggi engagement-nya adalah teks.

Aktivitas Reply dan Retweet dalam akun Twitter@safenetvoice lebih banyak dari unggahan yang mereka lakukan. Retweet yang dilakukan oleh akun Twitter SAFEnet bukan karena mereka kekurangan konten, tetapi lebih kepada beberapa kerjasama yang dilakukan oleh dengan mitra SAFEnet. Seperti mengadvokasi sebuah kasus bersama dengan lembaga pengada layanan lainnya, mengadakan penelitian, hingga menjadi narasumber. Retweet yang dilakukan oleh akun Twitter SAFEnet juga masih berkaitan dengan isu yang mereka perjuangkan. Dalam konteks kampanye "Awas KBGO!" masih relevan dengan pesan kampanye yang ingin disampaikan sehingga dapat menambah literasi pengurus SAFEnet dan followers akun Twitter SAFEnet. SAFEnet juga lebih banyak membuat cuitan dengan kombinasi media, baik foto, link, dan gif. Sedangkan, audiens Twitter lebih menyenangi cuitan yang hanya berupa teks saja.

Twitter memiliki sejumlah kelebihan sebagai media sosial microblogging yang sederhana, memiliki karakter yang fleksibel, dan dapat diikuti oleh jumlah akun yang tak terbatas. Twitter seharusnya dapat dimanfaatkan lebih maksimal oleh Tim Kampanye "Awas KBGO!". SAFEnet secara umum masih kurang memaksimalkan segala fitur yang ada di Twitter. Utamanya dengan membuat tweet secara berkala. 
Menurut pandangan peneliti, Tim Kampanye "Awas KBGO!" dapat memanfaatkan akun TwitterSAFEnet@safenetvoice untuk membuat lebih banyak utas (thread) tentang isu kekerasan berbasis gender online. Pesan yang disampaikan dapat berupa pembedahan kasus yang menyentuh emosi followers. Terlebih sampai dengan saat ini, SAFEnet dinilai sebagai satu-satunya organisasi yang memiliki kredibilitas untuk membicarakan tentang digital security di Indonesia. Pengikut dari akun Twitter SAFEnet pun dari berbagai kalangan mulai dari akademisi, aktivis, hingga figur publik yang memiliki pengikut ribuan.

Peneliti menemukan adanya potensi Twitter SAFEnet bisa meningkatkan partisipasi laki-laki dalamKampanye“"AwasKBGO!'Perludiketahui, secara umum salah satu tantangan kampanye anti kekerasan berbasis gender terutama perempuan adalah kurangnya keterlibatan laki-laki. Twitter SAFEnet lebih banyak diikuti oleh pengguna laki-laki yakni $56 \%$. Selain itu, dalam Twitter SAFEnet juga lebih banyak interaksi dengan laki-laki yaitu $62 \%$. Oleh karena itu, hal ini patut menjadi pertimbangan bagi Tim Kampanye "Awas KBGO!" untuk mengoptimalkan penggunaan Twitter dalam menyampaikan pesan-pesan Kampanye "Awas KBGO!"

Berdasarkan uraian yang telah peneliti jabarkan, peneliti menarik kesimpulan bahwa Tim Kampanye "Awas KBGO!" tetap harus mengoptimalkanpenggunaanmediasosialTwitter terutama akun utama SAFEnet @safenetvoice untuk menyampaikan pesan-pesan kampanye. Beberapa kesimpulan yang peneliti elaborasi dari hasil analisis Keyhole Social Media Analytics adalah sebagai berikut: Pertama, pengikut dan interaksi dalam akun Twitter@safenetvoice didominanasi laki-laki. Dengan demikian, Kampanye "Awas KBGO!" dapat meningkatkan partisipasi laki-laki melalui Twitter. Kedua, Tim Kampanye "Awas KBGO!" harus lebih kreatif dalam mengemas pesan dalam bentuk teks untuk media sosial Twitter. Karakteristik Twitter adalah media sosial microblogging sehingga tim kampanye dapat membuat utas terkait Kekerasan Berbasis Gender Online (KBGO) dan literasi keamanan digital. Perlu diingat bahwa fungsi gambar dan video adalah penunjang teks. Oleh karena itu, diharapkan tim kampanye "Awas KBGO!" dapat membuat pesan yang kreatif dan tidak menitikberatkan pada gambar dan video.

\section{Kekuatan dan Tantangan Penggunaan Daya Tarik Pesan (Message Appeals) dalam Kampanye "Awas KBGO!"}

Kampanye "Awas KBGO!" bertujuan untuk meningkatkan awareness publik tentang Kekerasan Berbasis Gender online (KBGO). Untuk mencapai tujuan tersebut, salah satu strategi pesan yang dilakukan adalah menggunakan message appeals (daya tarik pesan) yang terbagi menjadi dua yaitu reasoning appeals (daya tarik alasan) dan emotional appeals (daya tarik emosional). Penggunaan beberapa taktik daya tarik pesan (message appeals) sebagai strategi pesan kampanye ini sesuai yang disebutkan oleh Smith (2013).

Adapun penggunaan reasoning appeals (daya tarik alasan) diantaranya adalah dengan penggunaan data, analogi, dan simulasi. Kemudian, penggunaan emotional appeals (daya tarik emosional) dalam pesan kampanye "Awas KBGO!" menimbulkan dua perasaan yaitu positif dan negatif. Berdasarkan hasil analisis peneliti, ditemukan bahwa pesan kampanye yang menimbulkan perasaan negatif lebih dominan digunakan dibandingkan dengan pesan kampanye yang menimbulkan perasaan positif. Perasaan negatif yang ditimbulkan didominasi oleh penggunaan pendekatan rasa takut (fear appeals). Hal ini sesuai dengan pernyataan dari Tim Kampanye "Awas KBGO!" yang ingin memberikan warning melalui kampanye ini. Akan tetapi, penggunaan message appeals yang didominasi dengan timbulnya perasaan negatif ini memiliki kekuatan dan tantangan.

Peneliti mengelaborasi hasil penelitian dengan teori EPPM (Extended Parallel Process Model) yang diungkapkan oleh Witte (1993, 1996). Dampak dari fear appeals (pendekatan rasa takut) diantaranya adalah: (1) Tidak ada respon, artinya target audiens beranggapan pesan kampanye tidak menakutkan. Dalam konteks kampanye "Awas KBGO!", contohnya pesan 


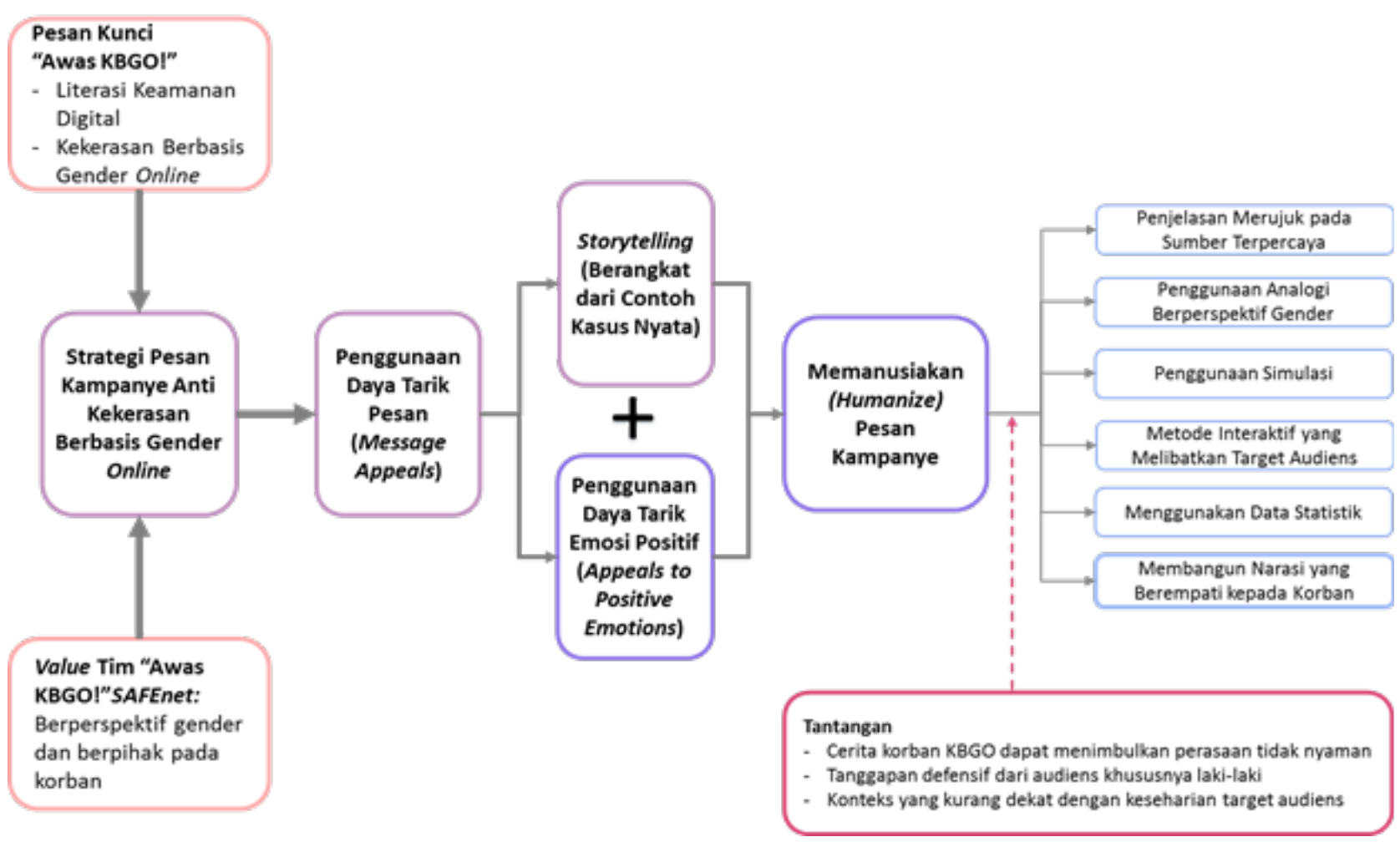

Gambar 3. Model Ideal Penggunaan Message Appeals dalam Strategi Pesan Kampanye Anti Kekerasan

Sumber: Analisis Peneliti, 2020 Berbasis Gender Online

mengenai hal-hal yang harus dilakukan apabila konten intim disebarkan tanpa persetujuan. Visualisasi gambar yang dipilih untuk pesan ini hanya perempuan dengan raut muka ketakutan. Gambaran visualisasi ini kurang bahaya dan tidak cukup kuat dibandingkan dengan hasil visualisasi chat tentang ancaman penyebaran dalam aplikasi pesan (Tabel 5); (2) Kontrol bahaya, artinya target audiens merasa takut dengan pesan, kemudian ketakutan tersebut diiringi dengan tindakan nyata agar tidak menjadi korban. Contohnya adalah pesan tentang Hati-Hati Modus Kekerasan Berbasis Gender Online Berkedok Penelitian (Tabel 5). Dalam pesan tersebut dijelaskan modus operandi hingga cara pencegahannya; (3) Kontrol ketakutan adalah kondisi ketika pesan persuasi membuat orang takut, tetapi ketakutan tersebut tidak diiringi dengan efikasi (keinginan untuk mengubah perilaku) sesuai dengan pesan kampanye. Contohnya adalah pesan yang menampilkan potret Kekerasan Berbasis Gender Online dengan bercerita.
Target audiens bisa jadi takut tetapi belum dapat mengubah perilakunya karena merasa dirinya tidak akan menjadi korban Kekerasan Berbasis Gender Online. Target audiens mungkin saja masih dengan tidak sadar mengumbar data pribadinya di media sosial atau tidak berhatihati ketika menggunakan aplikasi kencan.

Kekuatan pesan-pesan kampanye "Awas KBGO!" selama ini adalah penjelasan yang berbasis data statistik dan fakta. Mengingat istilah "Kekerasan Berbasis Gender Online" sendiri merupakan sesuatu yang baru di masyarakat.

Penggunaan fear appeals hanya efektif ketika disertai contoh kasus yang menyita perhatian dan sedang ramai diperbincangkan oleh publik di media sosial. Selebihnya, fear appeals menjadi tantangan karena membuat target audiens kampanye tidak nyaman dengan pesan yang disampaikan serta mendapat tanggapan defensif dari audiens khususnya laki- 
laki. Terlebih pesan-pesan kampanye "Awas KBGO!" sarat dengan kata-kata yang berkaitan dengan gender, kekerasan, dan keamanan digital. Tim “Awas KBGO!” mengakui bahwa isu yang mereka kampanyekan adalah isu sensitif sehingga penggunaan fear appeal justru perlu dihindari.

Praktisi Kampanye Komunikasi dan Public Relations dari CPROCOM, Dr. Emilia Bassar menyarankan untuk memperbanyak pesan yang positif bahkan menghibur dengan cara yang lebih kreatif. "...Saya tuh mempelajari masalah itu tetapi saya mungkin pada kelompok yang lebih suka kalau kita campaign atau menyampaikan pesan lebih persuasif, informatif sudah pasti ya. Lebih persuasif dan ketika orang membacanya lebih nyaman. Tidak membuat orang jadi ikut marah, jadi ikut malah terprovokasi. Kalau saya lebih sukanya sih yang membuat orang jadi meningkat awareness-nya lalu lebih paham persoalannya. Kemudian kadangkadang malah lebih menghibur karena ada orang lain yang turut mendukung kita, gitu ya. Dengan cara-cara yang lebih kreatif sehingga orang menjadi terhibur..'(Emilia Bassar, 15 Agustus 2020)

Penggunaan message appeals yang ideal dalam strategi pesan kampanye anti kekerasan berbasis gender online peneliti ilustrasikan dalam Gambar 3. Sebelum menyusun strategi pesan kampanye, sebuah organisasi perlu untuk merefleksikan tentang nilai-nilai yang dianut oleh organisasi dan selalu mengacu pada pesan kunci kampanye. Tim "Awas KBGO!" SAFEnet memegang nilai untuk senantiasa berperspektif gender dan berpihak pada korban. Kemudian pesan kunci kampanye "Awas KBGO!" berkaitan dengan literasi keamanan digital dan KBGO. Tahapan selanjutnya adalah menentukan strategi pesan yang menggunakan daya tarik pesan (message appeals).

Dalam menggunakan daya tarik pesan, peneliti menemukan adanya potensi agar Tim Kampanye "Awas KBGO!" lebih banyak menggunakan daya tarik pesan yang menimbulkan emosi positif. Hal ini berbeda dengan temuan sebelumnya yang menyebutkan bahwa fear appeals efektif digunakan dalam kampanye yang bertujuan untuk mengubah perilaku individu (Avery \& Park, 2018; Berto, 2015; Eriyanto \& Zarkasi, 2017; Guttman, 2015; Hornik et al., 2016; Zhao et al., 2019).

Kampanye "Awas KBGO!" adalah kampanye anti kekerasan. Kata kekerasan sendiri sudah menimbulkan kengerian. Membicarakan kekerasan tidak harus dinarasikan dan digambarkan dengan sesuatu yang tidak nyaman pula. Lebih baik, membuat narasi dengan memperbanyak contoh yang dekat dengan masyarakat melalui cerita (storytelling) dan menyentuh perasaan.

Perpaduan antara teknik storytelling yang berangkat dari contoh kasus nyata dan penggunaan daya tarik emosi positif (narasi positif) akan menghasilkan pesan yang humanize. Pesan kampanye dapat semakin efektif jika Tim Kampanye "Awas KBGO!" bisa memanusiakan pesan kampanye (humanize message). Memanusiakan pesan kampanye ini bisa dilakukan dengan cara meramu pesan berbasis data yang terpercaya disertai angka statistik, bahasa yang mudah dimengerti, penggunaan analogi dan simulasi yang berperspektif gender, berinteraksi dan melibatkan target audiens, serta membangun narasi yang berempati pada korban. Memanusiakan(Humanize)pesankampanyepada akhirnya akan lebih diingat karena menyentuh emosi dan menarik empati target audiens terhadap korban kekerasan berbasis gender online.

Dalam merumuskan pesan yang humanize, perlu diingat bahwa kampanye anti kekerasan berbasis gender online memiliki sejumlah tantangan, diantaranya adaah: (1) Cerita dari korban kekerasan berbasis gender online dapat menimbulkan perasaan tidak nyaman; (2) Tanggapan defensif dari target audiens yang tidak setuju dengan isu kesetaraan gender, terutama audiens laki-laki; (3) Konteks yang kurang dekat dengan keseharian masyarakat. Tim kampanye harus menghindari bahasa yang eksklusif dan menggunakan bahasa yang mudah dipahami sehingga dapat menjangkau target audiens yang lebih luas. 


\section{Simpulan}

Kampanye "Awas KBGO!" adalah sebuah kampanye sosial yang bertujuan untuk meningkatkan awareness publik tentang Kekerasan Berbasis Gender Online (KBGO). Taktik message appeals (daya tarik pesan) digunakan sebagai strategi pesan, yaitu reasoning appeals (daya tarik alasan) dan emotional appeals (daya tarik emosional). Penggunaan pesan kampanye yang menimbulkan perasaan negatif berupa fear appeals (daya tarik ketakutan) lebih dominan dibandingkan dengan pesan kampanye yang menimbulkan perasaan positif.

Kekuatan pesan-pesan kampanye "Awas KBGO!" selama ini adalah penjelasan yang berbasis data statistik dan fakta. Mengingat istilah "Kekerasan Berbasis Gender Online" sendiri merupakan sesuatu yang baru di masyarakat. Penggunaan fear appeals hanya efektif ketika disertai contoh kasus yang menyita perhatian publik di media sosial. Fear appeals justru menjadi tantangan karena membuat target audiens kampanye tidak nyaman dengan pesan yang disampaikan serta mendapat tanggapan defensif dari audiens khususnya laki-laki.

Sub Divisi Digital At-Risks sebagai penyelenggara Kampanye "Awas KBGO!" perlu mengevaluasi pesan-pesan kampanye “Awas KBGO!". Peneliti menyarankan agar memperbanyak pesan yang memanusiakan (humanize) dengan penggunaan narasi positif dan teknik storytelling yang berangkat dari kasus atau cerita korban KBGO sehingga menarik empati publik bukan hanya menakut-nakuti.

Penelitian tentang strategi pesan dalam kampanye anti kekerasan terhadap gender selanjutnya diharapkan dapat memotret efektivitas pesan kampanye anti kekerasan berbasis gender online ini secara kuantitiatif dari kacamata target audiens. Ada potensi kampanye anti kekerasan berbasis gender online ini perlu menargetkan orang tua karena anak-anak rentan menjadi korban kekerasan siber. Diharapkan dapat memotret daya tarik pesan kampanye yang paling efektif untuk digunakan di Indonesia berdasarkan gender. Hal ini dikarenakan kampanye anti kekerasan berbasis gender online masih terkesan menyasar perempuan saja, padahal kampanye ini juga menyasar laki-laki dan ragam gender lainnya.

Penelitian ini memberikan kontribusi berupa rekomendasi kebijkan baru mengenai humanize message appeals untuk kampanye anti kekerasan berbasis gender online merupakan alternatif taktik bagi perancang pesan kampanye sosial. Utamanya kampanye bertema kekerasan yang bertujuan untuk mengubah individu dan akhirnya membawa perubahan sosial.

\section{Daftar Pustaka}

Avery, E. J., \& Park, S. (2018). HPV vaccination campaign fear visuals: An eye-tracking study exploring effects of visual attention and type on message informative value, recall, and behavioral intentions. Public Relations Review, 44(3), 321-330. https:// doi.org/10.1016/j.pubrev.2018.02.005

Basuki, B., \& Ashrianto, P. D. (2020). Implementasi Integrated Marketing Communications Vasektomi dalam Upaya Peningkatan Akseptor $\mathrm{Kb}$ Pria Lestari. Jurnal Ilmu Komunikasi, 17(3), 280. https://doi.org/10.31315/jik.v17i3.3777

Berto, A. R. B. (2015). Pendekatan Rasa Takut Sebagai Strategi Pesan Persuasif dalam Iklan Keselamatan Jalan. Jurnal Penelitian Dan Pengembangan Komunikasi Dan Informatika, 6(2), 69-81. Creswell, J. W. (2007). Qualitative Inquiry \& Research Design. In Sage Publications, Inc. https://doi.org/10.1111/1467-9299.00177

Eriyanto, \& Zarkasi, I. (2017). Kampanye Bahaya Rokok dan Pendekatan Rasa Takut. Jurnal ASPIKOM, 3(2), 340-357. Guttman, N. (2015). Persuasive Appeals in Road Safety Communication Campaigns: Theoretical Frameworks and Practical Implications from The Analysis of a Decade of Road Safety Campaign Materials. Accident Analysis and Prevention, 84, 153-164. https://doi.org/10.1016/j.aap.2015.07.017 
Hornik, J., Ofir, C., \& Rachamim, M. (2016). Quantitative evaluation of persuasive appeals using comparative meta-analysis. Communication Review. https://doi. org/10.1080/10714421.2016.1195204

Kholisoh, N. (2015). Strategi Komunikasi Public Relations dan Citra Positif Organisasi (Kasus Public Relations Rumah Sakit "X" di Jakarta). Jurnal Ilmu Komunikasi, 13(3), 195-209.

Komnas Perempuan. (2017). Lembar Fakta Catatan Tahunan (CATAHU) Komnas Perempuan Tahun 2017. Lembar Fakta Catatan Tahunan (CATAHU) Komnas Perempuan.

Komnas Perempuan. (2020). Kekerasan meningkat: Kebijakan penghapusan kekerasan seksual untuk membangun ruang aman bagi perempuan dan anak perempuan. Catahu: Catatan Tahunan Tentang Kekerasan Terhadap Perempuan, 1-109.

LBH APIK Jakarta. (2020). Siaran Pers: Refleksi Hari Kartini, Perempuan dan Kerentanan Terhadap Kekerasan Dalam Masa Pandemi Covid-19. Diakses pada November 4, 2020, dari http://www.lbhapik.org/2020/04/ siaran-pers-refleksi-hari-kartini.html

Miles, M. B., Huberman, A. M., \& Saldana, J. (2014). Qualitative Data Analysis: A Methods Sourcebook. Third Edition. In The SAGE Handbook of Applied Social Research Methods. Mueller, J., Brien-milne, L. O., \& Wandera, N. (2018). Technolog Y- Facilitated Gender- Ba Sed V Iolence: International Center for Research on Women.

Noble, G., Pomering, A., \& Johnson, L. W. (2014). Gender and message appeal: Their influence in a pro-environmental social advertising context. Journal of Social Marketing. https:// doi.org/10.1108/JSOCM-12-2012-0049

Novianti, D., \& Fatonah, S. (2018). Literasi Media Digital di Lingkungan Ibu-Ibu Rumah Tangga di Yogyakarta. Jurnal Ilmu Komunikasi, 16(1), 1. https:// doi.org/10.31315/jik.v16i1.2678
Perloff, R. M. (2017). The dynamics of persuasion: Communication and attitudes in the 21st century. In The Dynamics of Persuasion: Communication and Attitudes in the Twenty-First Century. https://doi.org/10.4324/9781315657714 SAFEnet. (2019). Memahami dan Menyikapi Kekerasan Berbasis Gender Online: Sebuah Panduan (Vol. 2). Smith, R. D. (2013). Strategic Planning for Public Relations. In Strategic Planning for Public Relations. https:// doi.org/10.4324/9780203081242

Venus, A. (2018). Manajemen Kampanye. Bandung: Simbiosa Rekatama Media. Wisanggeni, S. P. (2020). Rentan Ditipu, Kesadaran Keamanan Digital Masyarakat Indonesia Masih Rendah. Diakses December 30, 2020, dari https://www. kompas.id/baca/gaya-hidup/2020/02/28/ rentan-ditipu-kesadaran-keamanan-digitalmasyarakat-indonesia-masih-rendah/

Witte, K. (1993). Message and conceptual confounds in fear appeals: The role of threat, fear, and efficacy. Southern Communication Journal. https://doi. org/10.1080/10417949309372896

Witte, K. (1996). Fear as motivator, fear as inhibitor. In Handbook of Communication and Emotion. https://doi. org/10.1016/b978-012057770-5/50018-7

Yin, R. K. (2014). Case study research: Design and methods (5th ed.). In Thousand Oaks, CA: SAGE Publications. Zhao, X., Roditis, M. L., \& Alexander, T. N. (2019). Fear and Humor Appeals in "The Real Cost" Campaign: Evidence of Potential Effectiveness in Message Pretesting. American Journal of Preventive Medicine, 56(2), S31-S39. https://doi. org/10.1016/j.amepre.2018.07.033 